\title{
COVERAGE MOBILIZATION BY DIFFERENT NO-TILLAGE IN-LINE HANDLING MECHANISMS
}

\author{
Doi:http://dx.doi.org/10.1590/1809-4430-Eng.Agric.v35n1p 89-97/2015
}

\section{EVANDRO M. BRANDELERO ${ }^{1}$, AUGUSTO G. DE ARAÚJO ${ }^{2}$, RICARDO RALISCH ${ }^{3}$}

\begin{abstract}
Vegetation cover on soil acts positively in maintaining temperature and soil moisture, yet, it has been imposing specific operational conditions on seeders. The objective of this study was to evaluate performance of different mechanisms regarding straw mobilization, employed in a no-till seeder. The experimental area was conducted on clayey soil under no-tillage with a large quantity of sorghum residue. The experiment was established in a randomized block design, as the treatments consisted of a combination of two mechanisms at front of the furrow opener composed of cutting disc and row cleaners, and three mechanisms behind the seed furrower, covering discs prototype model M1, Spider and commercial model, with the combination of cutting disc and Spider model not being evaluated. We assessed the coverage permanence on soil index, vegetation mass on surface and inside the line. The treatment containing the row cleaner mechanism efficiently removed straw from the surface of sowing line as well as the return one acted on straw replacement. It was identified that use of the cutting disc at the front of seeder contributed to the increase of straw installation inside the line, three times more than in the row cleaner system when operating individually. Covering mechanism with row cleaners reduced straw inside the line and kept line covering similar to treatment of cutting disc operating alone.
\end{abstract}

KEYWORDS: Zea mays, seeder, furrowers.

\section{MOBILIZAÇÃO DA COB ERTURA VEGETAL POR DIFERENTES MECANISMOS EM SEMEADURA DIRETA}

RESUMO: A cobertura vegetal sobre o solo age positivamente na manutenção da temperatura e da umidade do solo; contudo, vem impondo condições operacionais específicas às semeadoras. $\mathrm{O}$ objetivo do trabalho foi avaliar o desempenho de diferentes mecanismos quanto à mobilização da palha, empregados em uma semeadora direta. A área experimental foi conduzida em solo argiloso, em semeadura direta com alto volume de palha de sorgo. $\mathrm{O}$ experimento foi implantado no delineamento de blocos casualizados, sendo que os tratamentos consistiram na combinação de dois mecanismos à frente da haste sulcadora, compostos pelo disco de corte e rodas de varredura, e três mecanismos atrás do sulcador da semente, discos cobridores modelos protótipo M1, modelo comercial e Spider, sendo que a combinação disco de corte e modelo Spider não foi avaliada. Foram avaliados o índice de permanência da cobertura e a massa da cobertura vegetal na superfície e no interior da linha. $O$ tratamento que continha o mecanismo rodas de varredura removeu eficientemente a palha da superfície da linha de semeadura bem como os de retorno atuaram na reposição da palha. Constatou-se que o uso do disco de corte à frente da semeadora contribuiu para o aumento da introdução da palha no interior da linha, três vezes mais em relação ao sistema rodas de varredura, quando eles operam isoladamente. A utilização dos mecanismos cobridores adicionados às rodas de varredura reduziu a introdução de palha no interior da linha e manteve a cobertura sobre a linha, similar ao tratamento disco de corte operando isoladamente.

PALAVRAS-CHAVE: Zea mays, semeadora, sulcadores.

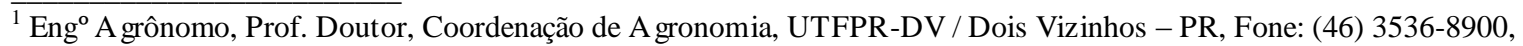
ebrandelero@utfpr.edu.br.

${ }^{2}$ Eng $^{\circ}$ A grícola, Pesquisador Doutor, Área de En genharia Agrícola, IAPAR / Londrina - PR, agaraujo@iapar.br

${ }^{3}$ Eng $^{\mathrm{o}}$ A grônomo, Prof. Doutor, Departamento de Agronomia, UEL / Londrina - PR, ralisch@uel.br

Recebido pelo Conselho Editorial em: 18-6-2012

Aprovado pelo Conselho Editorial em: 27-7-2014
} 


\section{INTRODUCTION}

An essential component for the viability of no-tillage system is the maintenance of the soil surface coverage that consists of an important technique for productive capability of recovering degraded soils because of poor soil management (TORRES et al., 2008). Vegetation coverage, when deceased, is generally referred as "straw", and should preferably remain on sowing line aiming to protect soil surface as it improves water infiltration and reduces surface runoff (CARVALHO, 2009). Straw on soil surface acts on temperature maintenance and on the reduction of soil-water evaporation (ANDRADE, 2010), as well as on nutrient release for plant cycling (HEINZ et al., 2011; PINESE JÚNIOR et al., 2008) and weed control (THEISEN \& BIANCHI, 2010).

Nevertheless, the soil covered with straw imposes specific operational conditions on seeders, which has led to the development of special mechanisms to operate in the system (CASÃO JUNIOR et al., 2006). The plane disc, for instance, at the front of furrow openers, was projected to cut the straw and favor no-tillage (LEVIEN et al., 2011). However, in clayey soils, the high resistance to penetration of furrow opening components of seeders, associated to soil-water retention, has resulted in problems, such as irregular cut of vegetation, straw accumulation, misplaced line opening, soil adhesion on components, unevenness in sowing depth, inappropriate coverage and compaction of soil on seeds, affecting the uniformity of plant emergence (CORTEZ et al., 2007).

An alternative for the plane cutting disc is the row cleaner system that aims to move the straw away laterally, instead of cutting it, using as mechanism two engaged and sprocket wheels located at the front of the furrow opener (FALLAHI \& RAOUFAT, 2008; BRANDELERO et al., 2012). Another possibility of soil coverage mobilization is the use of mechanisms for straw return, known as drills, used in conventional seeders, since the employment of such mechanisms improve sowing quality in NTS, acting positively on maintenance of straw as well as soil on line (CASÃO JUNIOR et al., 2006).

An approach to quantify straw on soil surface after transition of seeder opening mechanisms is through coverage permanence on soil index, which indicates that higher the value, greater the action of seeder mechanisms in maintaining vegetation coverage on line similar to the original conditions (CORTEZ et al., 2007).

The objective of this study was to evaluate the performance of different mechanisms in sowing lines concerning straw mobilization, employed in direct seeder.

\section{MATERIAL AND METHODS}

The work was conducted in the experimental area of the Agronomic Institute of Paraná (IAPAR) in Londrina - PR - Brazil, at $23^{\circ} 37^{\prime} \mathrm{S}$ and $51^{\circ} 17^{\prime} \mathrm{W}$. The soil was classified as Dystroferric Red Latosol and was on no-tillage system for 21 years. The soil average density was $1.25 \mathrm{Mg} \mathrm{m}^{-3}$ at depth of 0.025 to $0.075 \mathrm{~m}^{2}$ and $1.36 \mathrm{Mg} \mathrm{m}^{-3}$ at depth of 0.1 to $0.15 \mathrm{~m}$. In addition, the soil-water a verage volumetric content was $30.7 \%$ at depth of 0.025 to $0.075 \mathrm{~m}$ and $36.3 \%$ at depth from 0.1 to $0.15 \mathrm{~m}$. Concerning density as well as water volumetric content, the procedures described by EMBRAPA (1997) were followed.

The experiment was implemented on soil covered with sorghum residue with $10.7 \mathrm{Mg} \mathrm{ha}^{-1}$ of dry mass, handled using a plant residue shredder. For the sowing operation, a tractor with rated power of $62.5 \mathrm{kw}(85 \mathrm{CV})$, weighting $4,420 \mathrm{~kg}$ was used, working on first gear and engine rotation of $1.500 \mathrm{rpm}$ enabling an average speed of $1,6 \mathrm{~m} \mathrm{~s}^{-1}$.

An adapted seeder Jumil 2040 brand (Jumil, Batatais, SP) was used for the implementation of treatments, with the following configuration: shank type fertilizer furrower, out of phase double disc type seed furrower, controller wheel of seed depth and plane compactor wheel. The experiment was established in a randomized block design with four repetitions and seven treatments, with these constituted of mechanisms for straw mobilization in sowing line. The treatments are described on 
Table 1, with treatment of cutting disc plus covering disc Spider model not being evaluated due to experimental area limitation. A sowing line of $30 \mathrm{~m}$ of length, $3 \mathrm{~m}$ apart from each other were the experimental plots. The used maize cultivar was AG1051 in the proportion of 8.0 seed s m${ }^{-1}$.

TABLE 1. Experimental treatments consisting of the combination of the straw mobilization mechanisms placed in front of the shank type furrower (anterior) and behind the depth controller wheels (posterior).

\begin{tabular}{lll}
\hline Treatments & Anteriors & Set Composition \\
\hline CD+CM & Cutting disc & Covering discs comercial model \\
\hline $\mathrm{CD}+\mathrm{M} 1$ & Cutting disc & Covering disc prototype M1 model \\
\hline $\mathrm{CD}$ & Cutting disc & No mechanism \\
\hline $\mathrm{RC}+\mathrm{CM}$ & Row cleaners & Covering disc comercial model \\
\hline $\mathrm{RC}+\mathrm{M} 1$ & Row cleaners & Covering disc prototype M1 model \\
\hline $\mathrm{RC}+\mathrm{SM}$ & Row cleaners & Covering disc Spider model \\
\hline $\mathrm{RC}$ & Row cleaners & No mechanism \\
\hline
\end{tabular}

The cutting disc mechanism consisted of a plane metallic disc, located at front of the other seeder active devices, and performed straw cutting function, using soil as protection (Figure 1-A). The mechanism, termed row cleaner (RC), consisted of two plane metallic discs presenting sharp edges in bezel, working engaged and moving through the contact of edges with soil, and when operating they moved straw laterally to the sowing line, without cutting it (Figure 1-B).

The posterior sets aimed to move the soil and straw from the side to center of line after sowing (Figure 1-C, D, and E), being placed alongside and after the seed furrower, in oblique position in relation to seeder movement, one in each side of sowing line. The models varied according to tool format. The MC model consisted of two concave metallic discs, with plane edge (Figure 1-C). The covers M1 model were two plane metallic discs with semicircular indentations, forming a jagged edge, distant from each other and placed in an oblique position in relation to sowing line (Figure 1-D). The covers MS model were two plane metallic discs similar to the RC, but placed to bring soil and straw in order to cover the sowing line (Figure 1-E).

In order to characterize the experimental area, undisturbed soil samples were collected using cylindrical rings $\left(100 \mathrm{~cm}^{3}\right)$ at two depths, 0.025 to $0.075 \mathrm{~m}$ and 0.1 to $0.15 \mathrm{~m}, 0.3 \mathrm{~m}$ away from the center of each parcel. After soil collection, the weighting was conducted (wet weight) and then kiln drying at $105^{\circ} \mathrm{C}$ until constant weight (dry weight) was achieved. After drying, the samples were weighted for the calculation of soil density and soil- water content (EMBRAPA, 1997). 

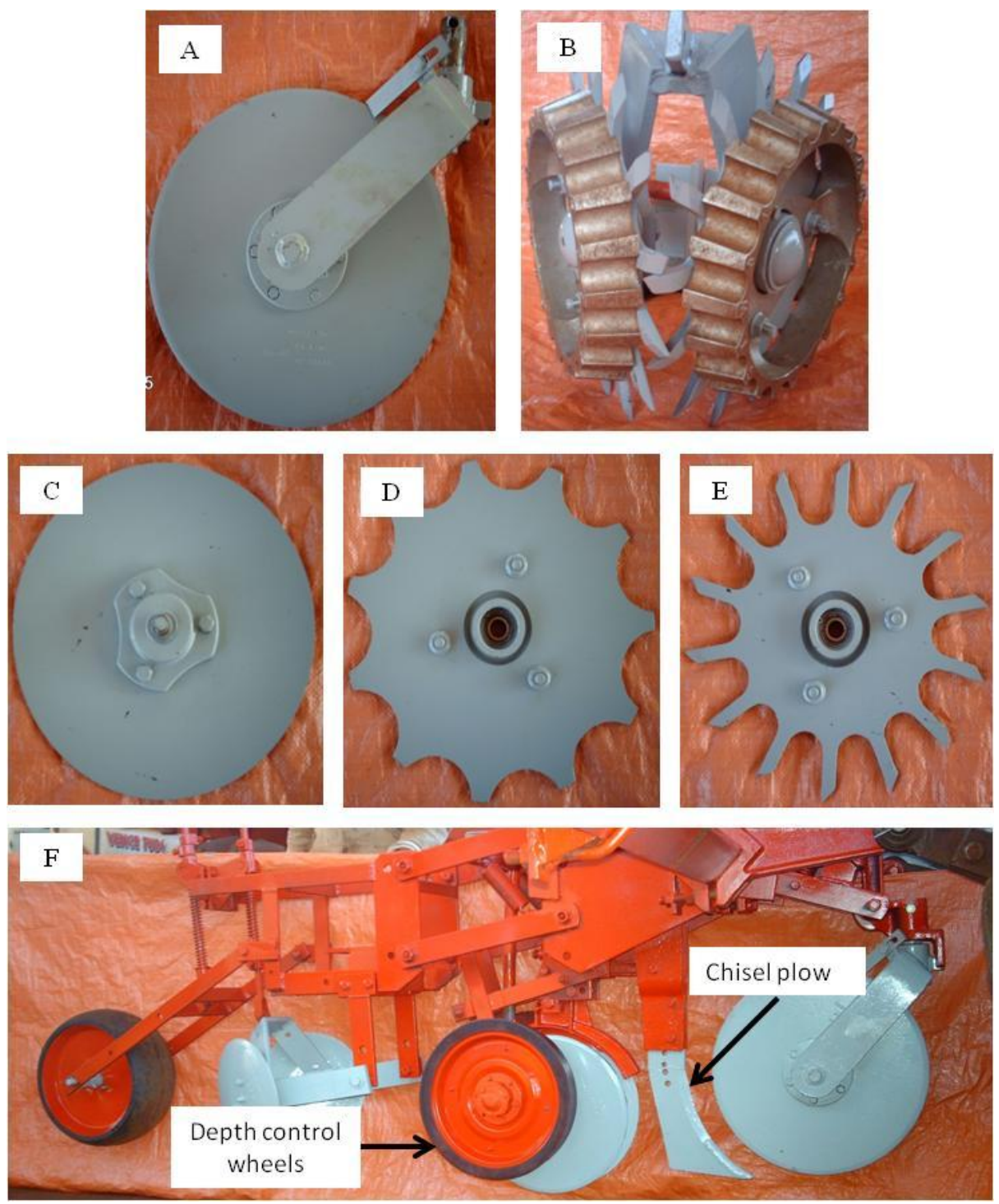

FIGURE 1. Straw mobilization mechanisms on no-till line: A (plane disc, PD); B (row cleaners, $\mathrm{RC}$ ); C (covering discs commercial model CM); D (covering wheels M1 model); E (covering wheels SM model) and F (general arrangement of mechanisms used in the no-till seeder).

The vegetal coverage percentage (straw) on the line surface was quantified using a measuring tape of $15 \mathrm{~m}$ length, with equidistant markings of $0.15 \mathrm{~m}$ (BRANDELERO et al., 2012). The measuring tape was placed on the sowing line surface in three places, one in the center and the others on two sides of line, $0.15 \mathrm{~m}$ away from the centre of each experimental parcel.

Straw percentage was obtained directly through the counting of number of points interceded with straw under the measuring tape in center and side of line, with the latter being analyzed through the average value of lateral observations. The percentages of soil coverage, before and after sowing, were used for the calculation of coverage permanence on soil index (CPS), which expresses the relation of coverage before and after sowing (CORTEZ et al., 2007).

Straw quantification on soil surface was through the collection of samples, after mechanism transition, in two places located opposite and transversal to sowing line (Figure 2), with three positions at the right side and three at the left side of the line. For straw collection, a metal frame with dimensions of $0.15 \times 0.30 \mathrm{~m}$ (Figure 2) was used, together with serrated blades to cut the straw inside the frame. Subsequently, the collected material was stored in paper bags with tags and then taken to kiln dryers until constant weight. Data of straw mass collected on right and left side, equally distant from the line center, was analyzed by the average value. The values were extrapolated to grams per square meter on line surface (BRANDELERO et al., 2012). 


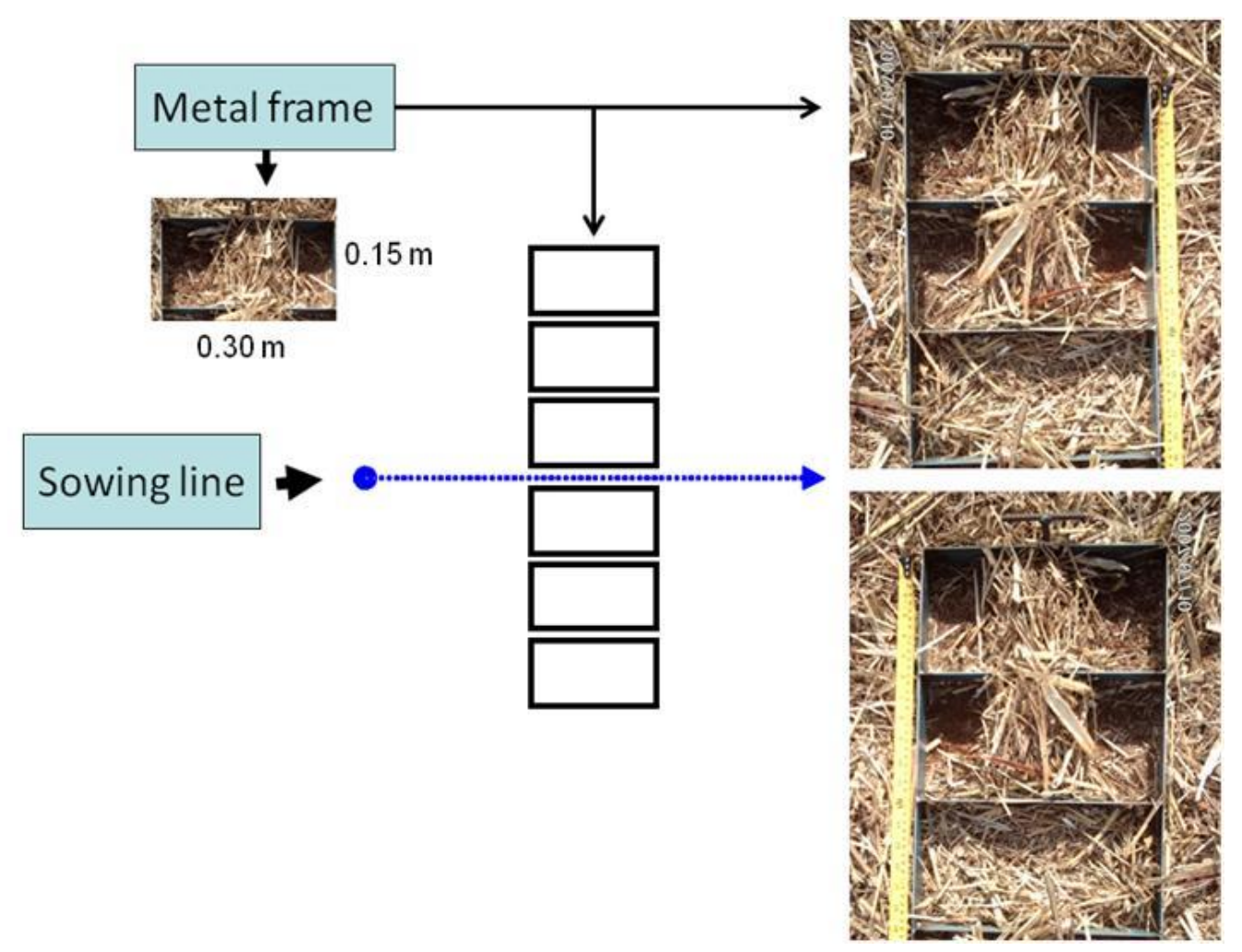

FIGURE 2. Location representation of the sampling of straw mass on the soil surface in relation to the sowing line.

Straw mass in the line interior was also evaluated, by manually removing the straw on sowing line surface and collecting soil with mobilized straw in the line interior (Figure 3-A) in seven samples per parcel, using metallic boxes with dimensions of $0.15 \times 0.10 \times 0.10 \mathrm{~m}$ (length, height and width). After soil collection, the samples were packed in plastic bags with identification. Subsequently, the samples were immersed in a water container, with the suspended straw being collected in a $3 \mathrm{~mm}$ mesh sieve (Figure 3-B) and the rest obtained through sample washing. The straw was packed in paper bags and kiln dried at $60^{\circ} \mathrm{C}$, until the constant weight was obtained. The results allowed an extrapolation of the achieved values for grams per cubic meter of mobilized soil according to the proposition of BRANDELERO et al. (2012).
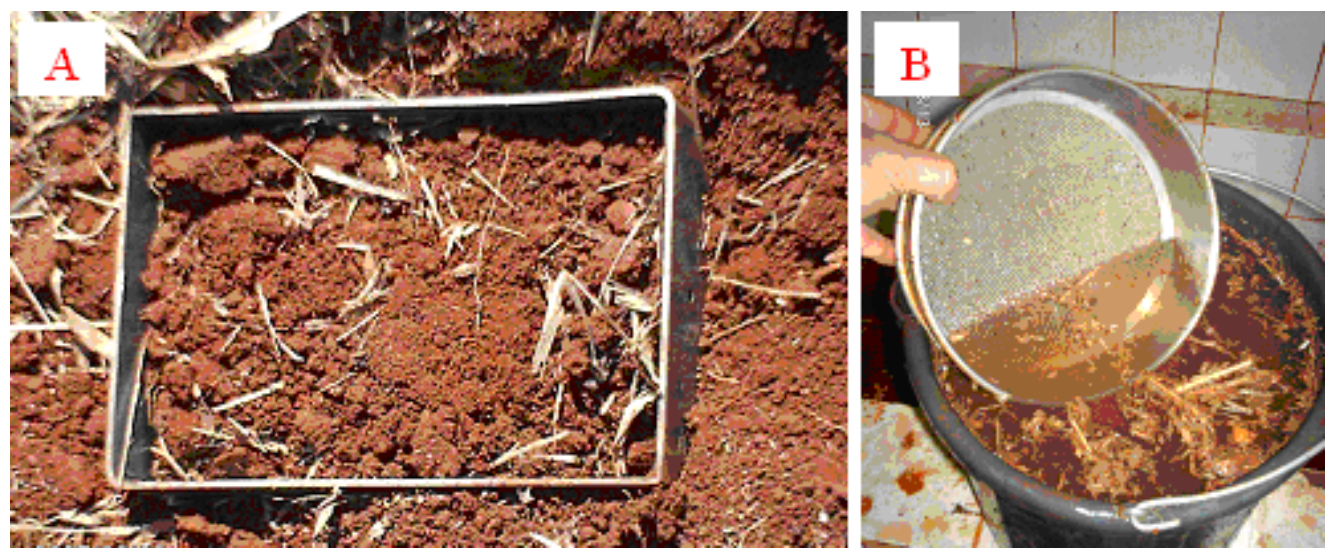

FIGURE 3. Quantification of straw mass in the sowing line interior. (A, metal box with soil in the line and B, immersion of the sample to collect straw from soil with the aid of a sieve).

After data collection, the values were submitted to Levene test for homoscedasticity verification. Afterwards, analysis of variance was conducted and when significant differences at $5 \%$ 
of error probability occured, the averages were compared to each other by the Tukey test at 5\% using the statistical program Statistica 6.1 version.

\section{RESULTS AND DISCUSSION}

After the implementation of treatments, the mechanisms produced different coverage permanence on soil indexes (CPS) in the center of sowing line (Table 2). CPS represents the relation between coverage mobilized by mechanisms with the original coverage (CORTEZ et al., 2007), showing the ability of mechanisms to preserve straw on sowing line.

TABLE 2. Coverage permanence on soil (CPS) on sowing line (\%) evaluated in two positions, side and center.

\begin{tabular}{llc}
\hline & \multicolumn{2}{c}{ Position on sowing line* } \\
\hline & Side & Center \\
\hline $\mathrm{CD}+\mathrm{CM}$ & & $\mathrm{CPS}(\%)$ \\
\hline $\mathrm{CD}+\mathrm{M} 1$ & $99.9 \mathrm{a}$ & $89.4 \mathrm{ab}$ \\
\hline $\mathrm{CD}$ & $99.0 \mathrm{a}$ & $93.8 \mathrm{a}$ \\
\hline $\mathrm{RC}+\mathrm{MC}$ & $99.0 \mathrm{a}$ & $67.5 \mathrm{c}$ \\
\hline $\mathrm{RC}+\mathrm{M} 1$ & $95.6 \mathrm{a}$ & $65.5 \mathrm{c}$ \\
\hline $\mathrm{RC}+\mathrm{SM}$ & $96.7 \mathrm{a}$ & $71.5 \mathrm{bc}$ \\
\hline $\mathrm{RC}$ & $94.2 \mathrm{a}$ & $76.9 \mathrm{abc}$ \\
\hline $\mathrm{CV}(\%)^{* *}$ & $99.9 \mathrm{a}$ & $1.0 \mathrm{~d}$ \\
\hline
\end{tabular}

* Means followed by distinct letters in column significantly differ from each other by the Tukey test at 5\% probability. **, variance coefficient, $\%$.

The most effective mechanism at maintaining straw on the center of sowing line was achieved with treatment CD+M1 (cutting disc associated with covering disc M1) (Table 02), significantly differing from treatments $\mathrm{RC}+\mathrm{M} 1$ (row cleaners associated with covering disc M1), followed by $\mathrm{CD}$ (cutting disc), RC+ MC (row cleaners with covering disc commercial model) and RC (row cleaners). The covers MC and M1, associated with $\mathrm{CD}$, presented statistically similar performances and both were superiors to the treatment $C D$ with no associations. This increase in index is due to the operational method of covering mechanis ms that, when moving, mobilize straw from side to center of sowing line. Similar results with covering mechanisms were accessed by CASÃO JUNIOR et al. (2001) when evaluating efficiency of ten precision seeders in clayey soil, with coverage of $13 \mathrm{Mg} \mathrm{ha}^{-1}$ of maize straw and dwarf "mucuna", in which $85 \%$ of vegetal coverage remained on sowing line, when a landing mechanism similar to $\mathrm{MC}$ was used.

The RC (row cleaners) were certainly effective at removing straw from the line center, reaching an average of $99 \%$ of reduction in CPS when operating individually (Table 2). This effect is due to mechanism configuration, which dislocates straw from center to side of the sowing line (FALLAHI \& RAOUFAT, 2008). The covering mechanisms MC, M1 and MS associated with RC, were efficient in the straw return when compared to RC operating individually, showing performances statistically similar to each other, inclusive with treatment $\mathrm{CD}$, the configuration most used commercially (Table 2).

Treatment $\mathrm{CD}$, when acting individually, resulted in coverage of sowing line equal to treatments that associated covers to $\mathrm{RC}$. Treatment $\mathrm{RC}+\mathrm{SM}$ presented great ability to return straw, evening- up to treatments that employed $\mathrm{CD}$ associated to covers.

The efficiency of straw removal by row cleaners increased the percentage of exposed soil surface, a clear conservationist disadvantage, according to determinations of BRANDELERO et al. (2012). Therefore, these must be always associated with relocation mechanisms of straw on sowing line so the production system benefits from the advantages of adequate seed positioning inside sowing line, maintenance of water and soil temperature, concluded by ARATANI et al. (2006). 
The most efficient treatments at the maintenance or addition of straw mass on sowing line placed between 0 to $0.15 \mathrm{~m}$ were $\mathrm{CD}+\mathrm{M} 1$ followed by $\mathrm{CD}$ (Table 03). It was also observed that treatment $\mathrm{CD}+\mathrm{CM}$ did not differ significantly from the other treatments, excepting $\mathrm{RC}$, that despite having a mobilization mechanism for straw return, showed little efficiency at the maintenance of straw mass on soil surface when associated to cutting disc.

TABLE 3. Alongside movement of the straw mass in relation to the sowing line $\left(\mathrm{g} \mathrm{m}^{-2}\right)$ and vertical movement of the straw into the furrow $\left(\mathrm{g} \mathrm{m}^{-3}\right)$.

\begin{tabular}{|c|c|c|c|c|}
\hline \multirow[b]{2}{*}{ Treatments } & \multicolumn{3}{|c|}{ Side movement (surface) } & \multirow{2}{*}{$\begin{array}{l}\text { Vertical movement } \\
\text { (Interior) }\end{array}$} \\
\hline & $0-0.15 \mathrm{~m}$ & $0.15-0.30 \mathrm{~m}$ & $0 . \overline{3} 0-0 . \overline{4} \overline{\mathrm{m}}$ & \\
\hline $\mathrm{CD}+\mathrm{CM}$ & $--\overline{7} \overline{5} \overline{a b}^{*}-$ & $715 \mathrm{~g} \mathrm{~m}^{-2}$ & $846 \mathrm{a}$ & $\begin{array}{l}\mathrm{g} \mathrm{m}^{-3} \\
3,372 \mathrm{~b}\end{array}$ \\
\hline$\overline{\mathrm{CD}+\mathrm{M} 1}$ & $1,150 \mathrm{a}$ & $819 \mathrm{~b}$ & $973 \mathrm{a}$ & $3,087 \mathrm{~b}$ \\
\hline$\overline{\mathrm{CD}}$ & $1,032 \mathrm{a}$ & $1,138 \mathrm{a}$ & $1082 \mathrm{a}$ & $4,215 \mathrm{a}$ \\
\hline $\mathrm{RC}+\mathrm{CM}$ & $592 \mathrm{~b}$ & $1,023 \mathrm{a}$ & $1231 \mathrm{a}$ & $2,380 \mathrm{c}$ \\
\hline $\mathrm{RC}+\mathrm{M} 1$ & $591 \mathrm{~b}$ & $1,134 \mathrm{a}$ & $1220 \mathrm{a}$ & $1,730 \mathrm{~d}$ \\
\hline$\overline{\mathrm{RC}+\mathrm{SM}}$ & $572 \mathrm{~b}$ & $1,050 \mathrm{a}$ & $982 \mathrm{a}$ & $2,210 \mathrm{~cd}$ \\
\hline$\overline{\mathrm{RC}}$ & $224 c$ & $1,252 \mathrm{a}$ & $1159 \mathrm{a}$ & $1,070 \mathrm{e}$ \\
\hline CV $(\%)^{* *}$ & 20.28 & 23.57 & 27.56 & 18.93 \\
\hline
\end{tabular}

* Means followed by distinct letters in column significantly differ from each other by the Tukey test at 5\% probability. **, variance coefficient, $\%$.

All treatments containing row cleaners adjoined as return mechanisms (Table 03) presented in average $44 \%$ less straw mass in the sowing line central position in relation to treatment CD, demonstrating that return mechanisms were not sufficient for the maintenance of initial straw levels. However, the quantity of straw returned by mobilization mechanisms on line (572 to $592 \mathrm{~g} \mathrm{~m}^{-2}$ ) is satisfactory in terms of soil conservation, since BRAIDA \& CASSOL (1999) achieved good results of erosion reduction between furrows at dosage of $400 \mathrm{~g} \mathrm{~m}^{-2}$ with maize straw.

The results of straw mass in position of 0 to $0.15 \mathrm{~m}$, in treatments including mechanism CD in its composition (Table 3), are above the ones found by FALLAHI \& RAOUFAT (2008) that achieved $308 \mathrm{~g} \mathrm{~m}^{-2}$ of maize straw using cutting disc. In the same position, observing RC treatment results, values above those observed by KORNECKI et al. (2009) were found. These authors applied the same mechanisms and achieved $134 \mathrm{~g} \mathrm{~m}^{-2}$ with straw deriving from succession of maize + soya in quantities of $3 \mathrm{Mg} \mathrm{ha}^{-1}$ and they were close to the results of FALLAHI \& RAOUFAT (2008), approaching $245 \mathrm{~g} \mathrm{~m}^{-2}$ of wheat straw in quantity of $3.8 \mathrm{Mg} \mathrm{ha}^{-1}$ in climate conditions of Iran. The superiority of results found in this study is associated to the high mass of sorghum straw in experimental conditions that were $10.7 \mathrm{Mg} \mathrm{ha}^{-1}$.

The results of straw incorporation in the line interior (Table 3) showed significant effects of the mechanisms. Treatments containing cutting discs incorporate more straw compared to mechanisms with row cleaners. Treatment CD introduced more straw in the line interior in relation to others, and KORNECKI et al. (2009) evidenced this with maize straw and by FALLAHI \& RAOUFAT (2008) with wheat straw.

The greatest straw incorporation in the interior of line is associated to low resistance of soil to penetration of cutting disc that, in this condition, move the straw without cutting it (BIANCHINI \& MAGALHÃES, 2004). Furthermore, the worst incorporation of straw in the line interior by mechanism RC and its associations is related to its pattern of handling straw, which dislocates it to the side of line (FALLAHI \& RAOUFAT, 2008; KORNECKI et al., 2009).

The greatest introduction of straw in the interior of sowing line, observed in treatments with cutting disc at the front, probably contributes for the establishment of air pockets, which prevent an 
adequate contact soil-seed, affecting germination, according to findings from ARATANI et al. (2006).

Treatment RC incorporated less straw in the line interior, differing significantly from other treatments (Table 3). The results showed that row cleaner treatments competently removed the straw, since the parcels presented $10.7 \mathrm{Mg} \mathrm{ha}^{-1}$. This effect of reducing straw in the interior of line was also found by FALLAHI \& RAOUFAT (2008) working with several mechanisms for straw mobilization.

By analyzing treatments $\mathrm{CD}$ and $\mathrm{RC}$ individually, it was observed that, in fact, only mechanism RC removed straw from the line center in greater proportions than the others were. This was not particularly surprising considering the CD mechanism's form of action, but it has a negative effect since it introduces three times more straw in line in relation to RC (Table 3). When investigating anterior and posterior mechanism association, it is verified that none of the covering mechanisms was able to restore the same amount of straw taken off by RC, needing to be improved. Still considering these associations with $\mathrm{RC}$, the evaluated covering mechanisms ended up introducing more straw in line than the cleaning mechanism itself, conceivably due to landing effect also fostered by evaluated posterior mechanisms.

Therefore, the straw return conducted by covering mechanisms in treatments $\mathrm{RC}+\mathrm{CM}$, $\mathrm{RC}+\mathrm{M} 1$ and $\mathrm{RC}+\mathrm{SM}$ assisted to increases of $164 \%, 162 \%$ and $155 \%$, respectively of straw on sowing line in comparison to RC. These results revealed that straw return by covering mechanisms adjoined to row cleaners must be improved regarding performance, despite the satisfactory coverage of straw in treatment $\mathrm{RC}+\mathrm{CM}$ (Table 2 and 3 ).

\section{CONCLUSIONS}

The row cleaner treatment was the most efficient in straw removal on the sowing line surface. The adoption of covering mechanisms into cutting discs and row cleaners expand coverage of sowing line when compared to mechanisms operating individually. The system of row cleaners isolated or associated to return mechanisms reduces the introduction of straw in the line interior and retains a satisfactory coverage on line. The usage of cutting disc enhances straw incorporation in the line interior; however, the inclusion of covering mechanisms enables the management of vegetal coverage similar to original.

\section{AKNOWLEDGEMENTS}

This study was conducted with financial support from National Council for Scientific and Technological Development - CNPq. The first author also thank the State University of Londrina by means of the Post Graduation Program in Agronomy, for the opportunity to obtain the title of Doctor, as well as the Agronomic Institute of Paraná - IAPAR for the assistance in conduction of the project.

\section{REFERENCES}

ANDRADE, J.G. Influência dos resíduos vegetais na superfície do solo na dinâmica de evaporação da água e temperatura do solo. 2010. 92f. Dissertação (Mestrado em Ciência do Solo) Universidade Federal de Santa Maria, Santa Maria, 2010.

ARATANI, R.G.; MARIA, I.C. de; CASTRO, O.M. de; PECHE FILHO, A.; DUARTE, A.P.; KANTHACK, R.A.D. Desempenho de semeadoras-adubadoras de soja em Latossolo Vermelho muito argiloso com palha intacta de milho. Revista Brasileira de Engenharia Agricultura Ambiental, Campina Grande, v.10, n.2, p.517-522, 2006.

BIANCHINI, A.; MAGALHÃES, P.S.G. Comportamento da palha de cana-de-açúcar submetida ao corte por meio de ensaios de bancada. Revista Brasileira de Engenharia Agrícola e Ambiental, Campina Grande, v.8, n.2/3, p.304-310, 2004. 
BRAIDA, J.A.; CASSOL, E.A. Relações da erosão em entressulcos com o tipo e com a quantidade de resíduo vegetal na superfície do solo. Revista Brasileira de Ciência do Solo, Viçosa, MG, v.23, n.3, p.711-721, 1999.

BRANDELERO, E.M.; ARAUJO, A.G.; RALISCH, R. Desempenho de uma semeadora direta equipada com diferentes mecanismos para o manejo da palha na linha. In: CONGRESSO BRASILEIRO DE ENGENHARIA AGRÍCOLA, 41., 2012, Londrina. Anais... Londrina. Associação Brasileira de Engenharia Agrícola, 2012. 1 CD-ROM.

CARVALHO, M.A.R. de Efeito da cobertura do solo e de práticas de controle de erosão nas perdas de água e solo por escoamento superficial. 2009. 120f. Tese (Doutorado em Irrigação e Drenagem) - Escola Superior de Agricultura Luiz de Queiroz, Universidade de São Paulo, Piracicaba, 2009.

CASÃO JUNIOR, R.; SIQUEIRA, R.; ARAÚJO, A.G. de Dinâmica de semeadoras-adubadoras diretas em Marechal Cândido Rondon - PR. Londrina, IAPAR, 2001. 26p.

CASÃO JUNIOR, R.; SIQUEIRA, R.; MEHTA, Y.R.; PASSINI, J.J. Sistema plantio direto com qualidade. Londrina: IAPAR, 2006. 212p.

CORTEZ, J.W.; FURLANI, C.E.A.; SILVA, R.P. da; CARVALHO FILHO, A. Parâmetros de avaliação no solo, na máquina e na planta sob plantio direto. Revista Plantio Direto, v.98, p.24-34, 2007.

EMBRAPA - Empresa Brasileira de Pesquisa Agropecuária, Centro Nacional de Ciência do Solo. Manual de métodos de análise do solo. Rio de Janeiro, 1997. Não paginado.

FALLAHI, S.; RAOUFAT, M.H. Row-crop planter attachments in a conservation tillage system: A comparative study. Soil \& Tillage Re search, Kidlington, v.8, n.98, p.27-34, 2008.

HEINZ, R.; GARBIATE, M.V.; NETO, A.L.V.; MOTA, L.H. de S.M.; CORREIA, A.M.P.; VITORINO, A.C.T. Decomposição e liberação de nutrientes de resíduos culturais de crambe e nabo forrageiro. Ciência Rural, Santa Maria, v.41, n.9, p.1549-1555, 2011.

KORNECKI, T.S.; RAPER, R.L.; ARRIAGA, F.J.; SCHW AB, E.B.; BERGTOLD, J.S. impact of rye rolling direction and different no - till row cleaners on cotton emergence and yield. American Society of Agricultural and Biological Engineers, Joseph, v.52, n.2, p.383-391, 2009.

LEVIEN, R; FURLANI, C.E.A.; GAMERO, C.A.; CONTE, O.; CAVICHIOLI, F.A. Semeadura direta de milho com dois tipos de sulcadores de adubo, em nível e no sentido do declive do terreno. Ciência Rural, Santa Maria, v.41, n.6, p.996-1002, 2011.

PINESE JÚNIOR, J.F.; CRUZ, L.M.; RODRIGUE, S.C. Monitoramento de erosão laminar em diferentes usos da terra. Sociedade \& Natureza, Uberlândia, v.20, n.2, p.157-175, 2008.

THEISEN, G.; BIANCHI, M.A. Semeadura com pouco revolvimento de solo como auxílio no manejo de plantas daninhas em milho. Planta Daninha, Viçosa, MG, v.28, n.1, p.93-102, 2010.

TORRES, J.L.; PEREIRA, M.G.; FABIAN, A.J. Produção de fitomassa por plantas de cobertura e mineralização de seus resíduos em plantio direto. Pesquisa Agropecuária Brasileira, Brasília, v.43, n.3, p.421-428, 2008. 